\title{
Rancang Bangun Sistem Informasi Pengelolaan Arsip Data Kerjasama Tri Dharma Perguruan Tinggi Menggunakan Metode Alphabetical Filing System
}

\author{
Mohamad Rully ${ }^{\# 1}$, Petrus Sokibi ${ }^{\# 2}$ Rinaldi Adam\# ${ }^{3}$ \\ Program Studi Teknik Informatika Universitas Catur Insan Cendekia \\ Jl. Kesambi No 202 Cirebon \\ ${ }^{1}$ rullym72@gmail.com \\ $\frac{2}{\text { petrus.sokibiecic.ac.id }}$
}

\begin{abstract}
The design of the Tri Dharma Collaboration Data Archive Management Information System of the University of Catur Insan Cendekia Cirebon aims to make it easier for the Institute for Research and Community Service (LPPM) in archiving data on collaboration, research activities and community service carried out by lecturers.

In designing this system, the author uses the alphabetical filing system method in the archiving method, this method is poured into the programming languages PHP and Javascript, then the collaboration data, research activities and community service will be stored in the MYSQL database, the software used is sublime text, XAMPP. , The browser and UML design making applications, and the hardware used is the Lenovo G41 notebook with a $2.2 \mathrm{GHz}$ AMD A8 APU Radeon processor.

Regarding the final results achieved, this application is expected to make it easier for LPPM to archive data on cooperation between the Tri Dharma University of Catur Insan Cendekia Cirebon University, the advantages of this system are its user-friendly appearance and easy to use, for deficiencies in the system data security is still not optimal, It is hoped that in developing this system data security can be improved again.
\end{abstract}

Keywords - Alphabetical Filing System, Collaboration, Information System, Institute for Research and Community Service

Abstrak_- Rancang Bangun Sistem Informasi Pengelolaan Arsip Data Kerjasama Tri Dharma Perguruan Tinggi Universitas Catur Insan Cendekia Cirebon bertujuan agar mempermudah Lembaga Penelitian dan Pengabdian Kepada Masyarakat (LPPM) dalam mengarsipkan data kerjasama, kegiatan penelitian dan pengabdian kepada masyarakat yang dilakukan oleh dosen.

Dalam perancangan sistem ini, penulis menggunakan metode Alphabetical filing system dalam metode pengarsipannya, metode ini dituangkan pada bahasa pemrograman PHP dan Javascript, kemudian data kerjasama, kegiatan penelitian dan pengabdian kepada masyarakat ini akan disimpan pada database MYSQL, software yang digunakan yaitu sublime text, XAMPP, Browser dan aplikasi pembuatan perancangan $U M L$, dan hardware yang digunakan adalah notebook Lenovo G41 dengan processor AMD A8 APU Radeon $2.2 \mathrm{GHz}$.

Mengenai hasil akhir yang dicapai, aplikasi ini diharapkan dapat mempermudah LPPM dalam mengarsipkan data kerjasama yang penyangkut tri dharma perguruan tinggi Universitas Catur Insan Cendekia Cirebon, kelebihan sistem ini tampilannya yang userfriendly dan mudah untuk digunakan, untuk kekurangan dalam sistem tersebut keamanan data masih belum maksimal, diharapkan dalam pengembangan sistem ini dapat ditingkatkan kembali keamanan datanya.

Kata Kunci — Alphabetical Filing System, Kerjasama, Lembaga Penelitian Dan Pengabdian Masyarakat, Sistem Informasi

\section{PENDAHULUAN}

Di zaman teknologi informasi yang berkembang pesat pada saat ini, dimana internet, smartphone, dan komputer telah membawa pengaruh besar dalam kehidupan manusia. Hampir di setiap tempat memfasilitasi layanan internet, agar masyarakat lebih mudah memperoleh akses internet.

Perkembangan perangkat lunak yang sangat pesat dewasa ini, menjadi kekuatan bagi dunia bisnis untuk mengembangkan usaha bisnisnya menjadi lebih luas lagi baik dari segi kuantitas maupun kualitas. Dalam dunia bisnis yang penuh dengan persaingan para pelakunya harus terus memikirkan cara-cara untuk terus survive dan jika mungkin mengembangkan skala bisnis mereka. Salah satu cara yang dapat dilakukan oleh para pelaku bisnis adalah dengan memanfaatkan teknologi komputer. Diantaranya adalah dengan menerapkan sistem komputerisasi dalam membantu proses rutin yang terjadi di perusahaan sehingga proses dapat 
dilakukan dengan lebih cepat dan efisien [1]. Selain itu perkembangan teknologi sudah menyentuh dalam berbagai bidang, salah satunya dalam bidang pendidikan, dimana memerlukan sebuah sistem untuk pengolahan data agar tersimpan secara aman dan tersusun rapih.

Universitas Catur Insan Cendikia merupakan perguruan tinggi yang berlokasi di kota Cirebon tepatnya di jalan Kesambi nomor 202, yang belum lama berubah menjadi Universitas, sebelumnya lembaga tersebut masih berupa sekolah tinggi dalam bidang ilmu komputer. Oleh sebab itu ada beberapa elemen yang ditambahkan sebagai salah satu syarat untuk pemenuhan akreditasi yaitu pengarsipan data kerjasama. Kerjasama ini menyangkut penelitian dan pengabdian kepada masyarakat yang mengacu pada misi Universitas Catur Insan Cendekia pada point 2 dan 3 yaitu berisi "2. Menyelenggarakan program penelitian berbasis teknologi informasi yang berkualitas untuk meningkatkan keunggulan universitas, dosen dan mahasiswa di tingkat nasional" dan "3. Menyelenggarakan program pengabdian kepada masyarakat berbasis teknologi informasi yang bermanfaat dan berdaya guna bagi pengembangan sumber daya manusia di komunitas dan masyarakat'. Kegiatan ini merupakan bagian dari Tri Dharma Perguruan Tinggi yaitu pengajaran, penelitian dan pengabdian kepada masyarakat. Oleh sebab itu penulis memiliki ide untuk membuat sebuah rancangan sistem pengarsipan data kerjasama yang menyangkut Tri Dharma Perguruan Tinggi dan diwujudkan dalam sebuah aplikasi menerapkan rancangan sistem yang telah dibuat. Penulis merancang sistem tersebut menggunakan sebuah metode pengarsipan agar dalam pembuatan sistem ini lebih terstruktur, baik dalam segi perancangan sistem ataupun langkah mengarsipkan sebuah data, metode yang penulis gunakan adalah metode Alphabetical Filing System. Alasan penulis mengunakan metode tersebut karena memiliki prosedur yang sesuai dengan pengarsipan dokumen.

Dalam beberapa penelitian sejenis terdapat sistem yang sama namun tidak menggunakan metode dalam pengelolaan data arsipnya seperti pada jurnal yang ditulis oleh Imasita, Gunawan, dan Hirman yang berjudul "Pengelolaan Model Sistem Pengelolaan Dokumen Tri Dharma Pada Politeknik Negeri Ujung Pandang Berbasis Web" [2] dan dalam penelitian sebelumnya pada jurnal yang ditulis oleh Welda dan Minartiningtyas yang berjudul "Sistem Informasi Pengelolaan Kerjasama Bidang Humas pada STMIK STIKOM Indonesia" [3], kemudian pada jurnal yang ditulis oleh D.Ratnasari dan H.A.Tawakal yang berjudul "Analisis Dan Perancangan Aplikasi Sistem Informasi Penelitian Dan Pengabdian Masyarakat Lppm Stt Terpadu Nurul Fikri" [4].

Sistem ini akan dibangun dalam berbasis web karena lebih mudah diakses oleh perangkat komputer dan smartphone yang terhubung ke internet, oleh karena itu penulis akan membuat sebuah sistem informasi yang berjudul : "Rancang Bangun Sistem Informasi Pengelolaan Arsip Data Kerjasama Tri Dharma Perguruan Tinggi Berbasis Web Menggunakan Metode Alphabetical Filling".

\section{Tinjauan Pustaka}

A. Definisi Rancang

Menurut Presman [5] dalam jurnal [6] Rancang merupakan serangkaian prosedur untuk menerjemahkan hasil analisa dari sebuah sistem ke dalam bahasa pemrograman untuk mendeskripsikan dengan detail bagaimana komponenkomponen sistem diimplementasikan.

\section{B. Definisi Bangun}

Menurut Presman [5] dalam jurnal [6] Bangun adalah kegiatan menciptakan sistem baru maupun mengganti atau memperbaiki sistem yang telah ada baik secara keseluruhan maupun sebagian.

\section{Sistem Informasi}

Sistem merupakan kumpulan komponen yang saling terhubung menjadi satu kesatuan untuk mencapai tujuan tertentu. Menurut G.B. Davis [7] Informasi adalah data yang telah diolah menjadi sebuah bentuk agar sistem informasi mempermudah memasukkan data pelanggan dan pelayanan transaksi pada toko jasa pembuatan pakaian.yangh berarti bagi penerimanya dan bermanfaat dalam mengambil keputusan saat ini atau mendatang [7]. Menurut M. Ray Jr. mengatakan bahwa informasi adalah data yang telah diproses, atau data yang memiliki arti [8]. Menurut Kertahadi, Sistem Informasi Manajemen (SIM) dapat didefinisikan sebagai suatu alat untuk menyajikan informasi dengan cara sedemikian rupa sehingga bermanfaat bagi penerimanya. Tujuannya adalah untuk menyajikan informasi guna pengambilan keputusan pada perencanaan, pemrakarsaan,pengorganisasian, pengendalian kegiatan operasi subsistem suatu perusahaan dan menyajikan sinergi organisasi pada proses [9].

\section{Kearsipan Elektronik}

Sistem kearsipan elektronik yaitu suatu sebuah algoritma yang dibuat untuk melakukan rekaman kegiatan agar data dapat dipelihara dan dapat dikelola secara sistematis. Arsip atau Dokumen merupakan rekaman kegiatan dalam suatu organisasi yang sangat penting untuk dipelihara dan dikelola. Sistem kearsipan elektronik pada dasarnya memiliki konsep yang sama dengan teknik kearsipan konvensional. Kearsipan konvensional memiliki kabinet yang secara fisik berfungsi untuk menyimpan dokumen-dokumen penting yang dimiliki perusahaan, maka sistem kearsipan berbasis komputer ini memiliki kabinet virtual yang di dalamnya berisi map virtual. Selanjutnya di dalam map virtual berisi lembaran-lembaran arsip yang telah dikonversi ke dalam bentuk file gambar (*.bmp, jpg, dll.) atau dokumen (*.doc, bet, dll) [10] .

\section{E. Kerjasama}

Kerjasama yaitu kegiatan yang dilakukan oleh 2 orang atau lebih atau antar kelompok yang bertujuan untuk memperoleh hasil yang diinginkan. Menurut Pamudji, [11] Kerjasama pada hakekatnya mengindikasikan adanya dua pihak atau lebih yang berinteraksi secara dinamis untuk mencapai suatu tujuan bersama. Dalam pengertian itu terkandung tiga unsur pokok yang melekat pada suatu 
kerangka kerjasama, yaitu unsur dua pihak atau lebih, unsur interaksi dan unsur tujuan bersama. Jika satu unsur tersebut tidak termuat dalam satu obyek yang dikaji, dapat dianggap bahwa pada obyek itu tidak terdapat kerjasama.Unsur dua pihak, selalu menggambarkan suatu himpunan yang satu sama lain saling mempengaruhi sehingga interaksi untuk mewujudkan tujuan bersama penting dilakukan. Apabila hubungan atau interaksi itu tidak ditujukan pada terpenuhinya kepentingan masing-masing pihak, maka hubungan yang dimaksud bukanlah suatu kerjasama. Suatu interaksi meskipun bersifat dinamis, tidak selalu berarti kerjasama. Suatu interaksi yang ditujukan untuk memenuhi kepentingan pihak-pihak lain yang terlibat dalam proses interaksi, juga bukan suatu kerjasama. Kerjasama senantiasa menempatkan pihak-pihak yang berinteraksi pada posisi yang seimbang, serasi dan selaras [12].

\section{F. Tri Dharma Perguruan Tinggi}

Dalam Kamus Besar Bahasa Indonesia, kata Tri Dharma adalah kata dalam bahasa Sanksekerta yang dibakukan. Tri berarti "Tiga", dan Dharma yang berarti "Kewajiban". Dengan demikian, pengertian Tri Dharma perguruan tinggi adalah tiga kwajiban yang harus dijalankan oleh perguruan tinggi dalam mengelola seluruh komponen yang ada di dalamnya (civitasakademika). Tri dharma perguruan tinggi merupakan dasar pola pikir dan menjadi kewajiban bagi mahasiswa sebagai kaum intelektual negara ini, tanggung jawab yang dipikul oleh mahasiswa tertuang dalam tri dharma perguruan tinggi karena mahasiswa memiliki posisi penting sebagai pejuang terdepan dalam perubahan bangsa kita ke arah yang lebih baik. Pernyataan ini menjadi terbukti ketika kita melihat sejarah bangsa ini dimana sebagian perubahan besar yang ada di negara ini dimulai oleh mahasiswa, dalam hal ini pemuda-pemudi Indonesia. Tri Dharma perguruan tinggi mencakup tiga hal penting yang harus dikembangkan, yaitu pendidikan, penelitian dan pengembangan serta pengabdian masyarakat. Tiga hal ini saling berkaitan antara satu sama lain sehingga harus diterapkan secara bersamaan. UU Nomor 20 Tahun 2003 tentang Sistem Pendidikan Nasional menyebutkan bahwa perguruan tinggi berkewajiban menyelenggarakan pendidikan dan pengajaran, penelitian, serta pengabdian kepada masyarakat (Pasal 20 Ayat 2). Berdasarkan pengertian tersebut di atas, maka maksud dari judul skripsi "Strategi Mahasiswa dalam Mengimplementasikan Tri Dharma Perguruan Tinggi" disini adalah langkah-langkah yang akan direncanakan, disusun dan diterapkan oleh mahasiswa dalam mencapai tujuan dari Tri Dharma Perguruan Tinggi [13].

\section{G. Alphabetical Filing System}

Sistem Abjad (Alphabetical Filing System) disini adalah sistem nama, yaitu sistem penyimpanan dokumen yang berdasarkan urutan abjad dari kata tangkap (nama) dokumen yang bersangkutan. Nama dapat terdiri dari dua jenis yaitu nama orang dan nama badan. Nama orang sendiri bisa terdiri dari nama lengkap dan nama tunggal, sedangkan nama badan terdiri dari nama badan pemerintah, nama badan swasta dan nama organisasi [14].

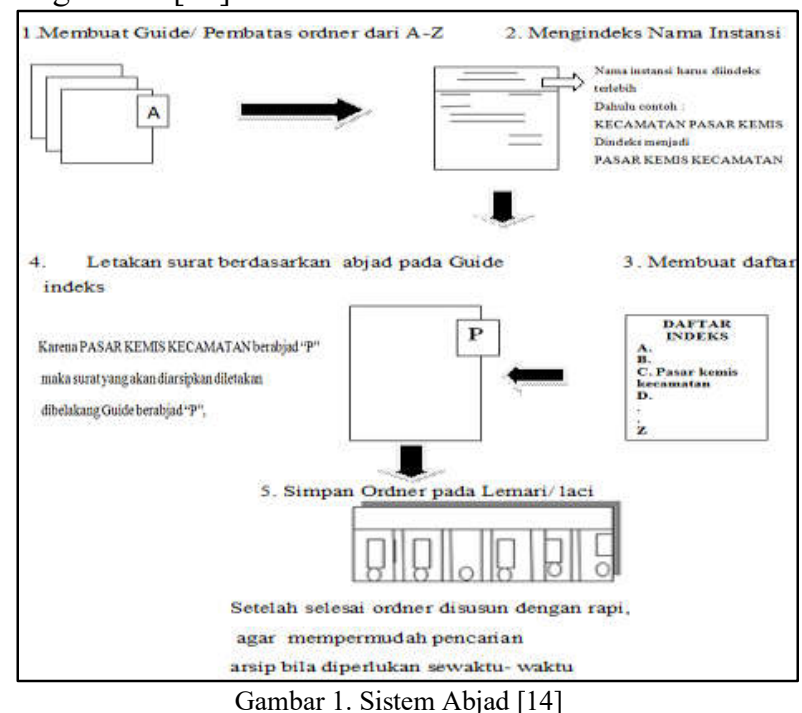

II. Metode Penelitian

Dalam penelitian ini, peneliti menggunakan metode waterfall karena cocok dalam perancangan dan pengembangan sebuah sistem. Berikut struktur metode waterfall :

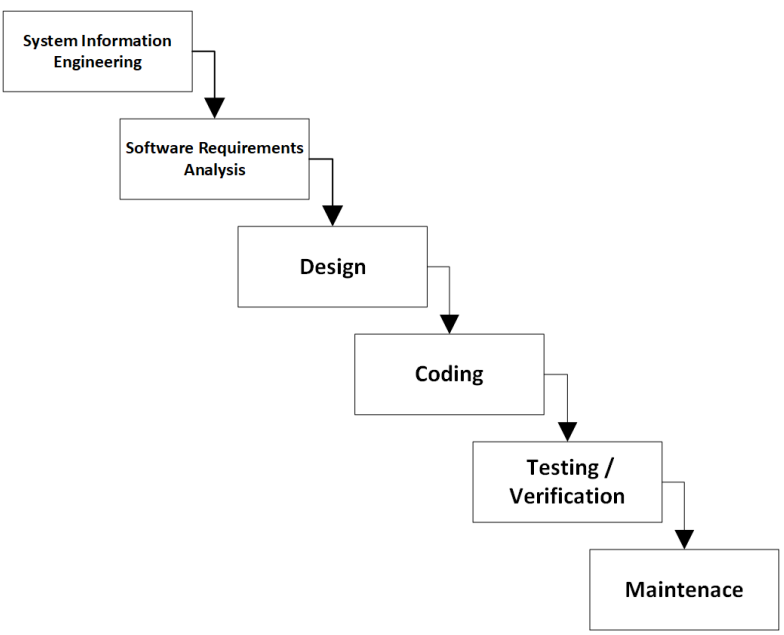

Gambar 2. Metode Waterfall [15]

Berikut keterangan dalam metode waterfall :

1. System Information Engineering and Modeling

Permodelan ini diawali dengan mencari kebutuhan dari keseluruhan sistem yang akan diaplikasikan ke dalam bentuk software. Hal ini sangat penting, mengingat software harus dapat berinteraksi dengan elemen-elemen yang lain seperti hardware, database dan sebagainya. Tahap ini sering disebut dengan Project Definition.

2. Software Requirements Analysis

Proses pencarian kebutuhan didahulukan dan difokuskan pada software. Untuk mengetahui sifat dari program yang 
akan dibuat, maka para software engineer harus mengerti tentang domain informasi dari software, misalnya fungsi yang dibutuhkan, user interface. Dari 2 aktivitas tersebut (pencarian kebutuhan sistem dan software) harus didokumentasikan dan ditunjukkan kepada pelanggan.

3. Design

Proses ini digunakan untuk mengubah kebutuhankebutuhan diatas menjadi representasi ke dalam bentuk "blueprint" software sebelum coding dimulai. Desain harus dapat mengimplementasikan kebutuhan yang telah disebutkan pada tahap sebelumnya. Seperti 2 aktivitas sebelumnya, maka proses ini juga harus didokumentasikan sebagai konfigurasi dari software.

\section{Coding}

Untuk dapat dimengerti oleh mesin, dalam hal ini adalah komputer, maka desain tadi harus diubah bentuknya menjadi bentuk yang dapat dimengerti oleh mesin, yaitu ke dalam bahasa pemrograman melalui proses coding. Tahap ini merupakan implementasi dari tahap desain yang secara teknis nantinya dikerjakan oleh programmer.

5. Testing / Verification

Sesuatu yang dibuat haruslah diujicobakan. Demikian juga dengan software. Semua fungsi-fungsi software harus diujicobakan, agar software berfungsi dengan baik, dan hasilnya harus sesuai dengan kebutuhan.

6. Maintenance

Sesuatu yang dibuat haruslah diujicobakan. Demikian juga dengan software. Semua fungsi-fungsi software harus diujicobakan, agar software bebas dari error, dan hasilnya harus sesuai dengan kebutuhan. [16]

Bahan penelitian yang digunakan adalah bersumber pada data primer dan data sekunder. Data primer didapat dari tempat penelitian. Sedangkan data sekunder didapat dari literatur buku referensi, artikel, jurnal, skripsi atau tesis mengenai pengarsipan data dengan metode alphabetical filing system.

\section{HASIL DAN PEMBAHASAN}

\section{A. Perancangan Sistem}

1. Use Case LPPM

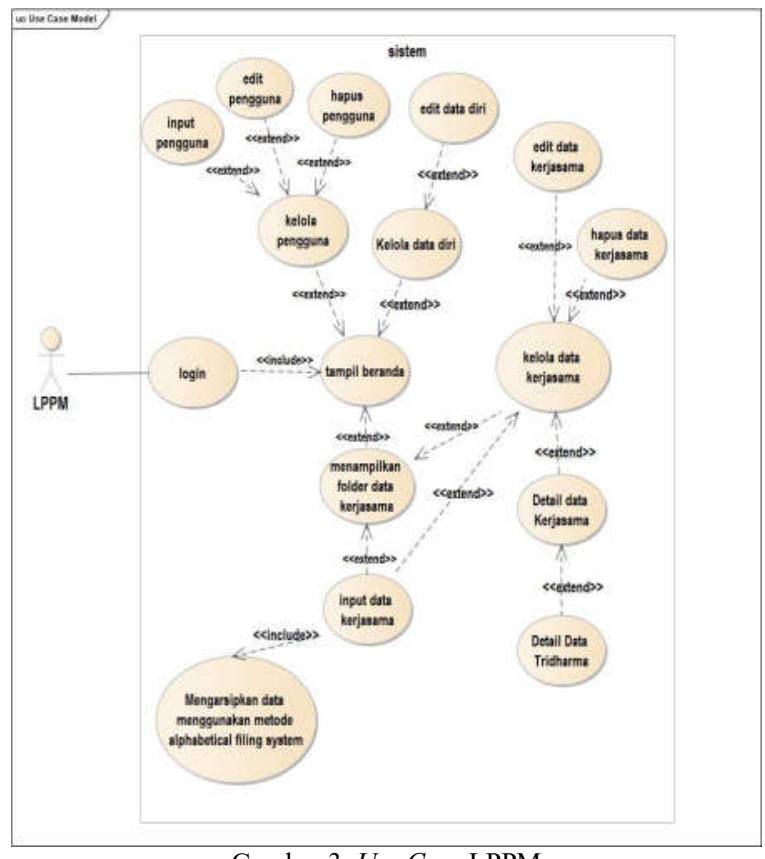

Gambar 3. Use Case LPPM

\section{Use Case Dosen}

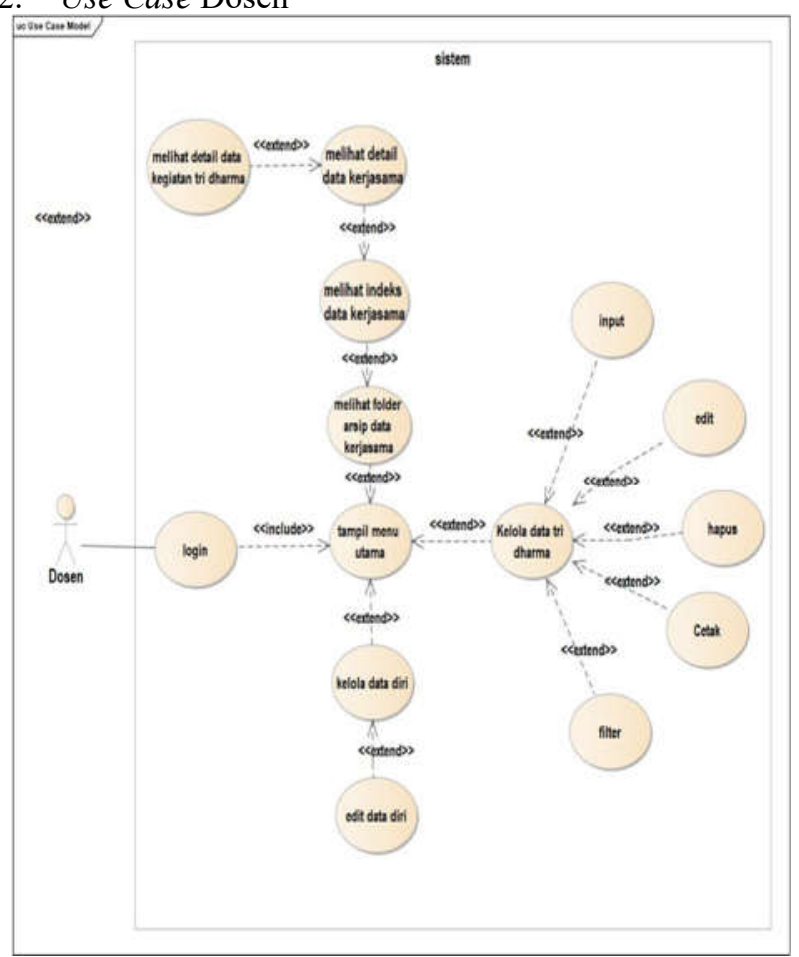

Gambar 4. Use Case Dosen 


\section{Activity Diagram LPPM}

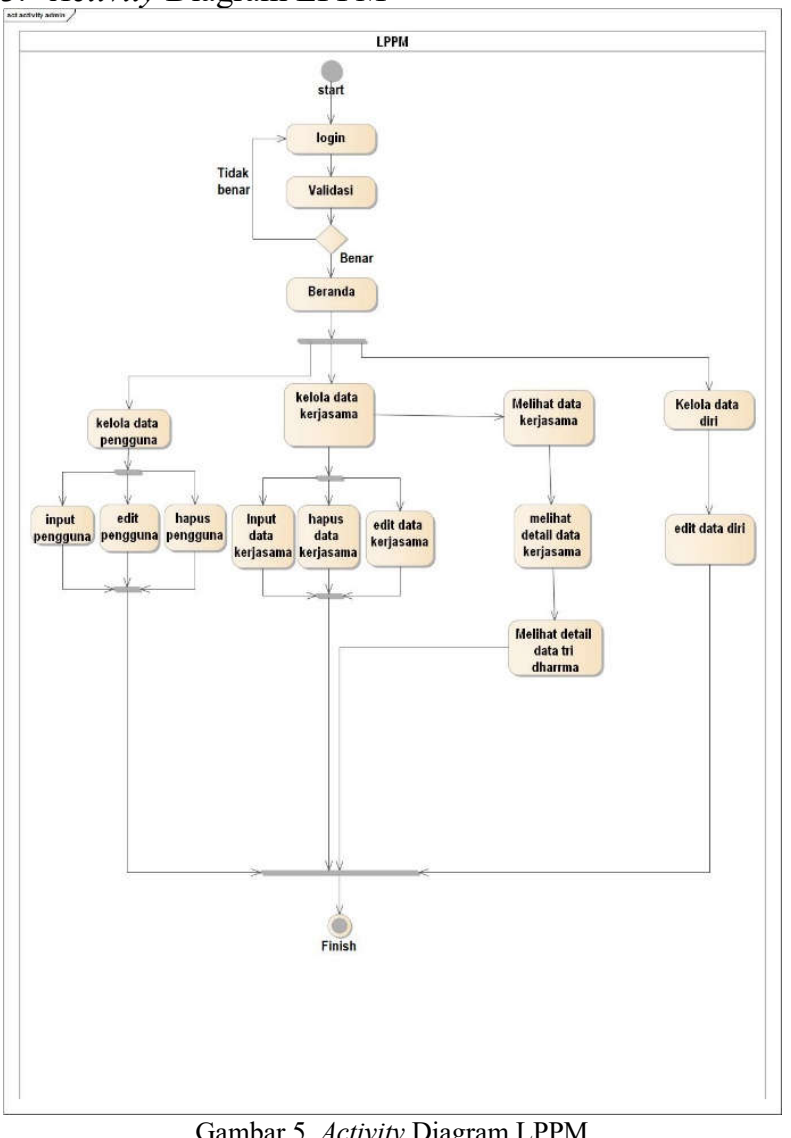

\section{Activity Diagram Dosen}

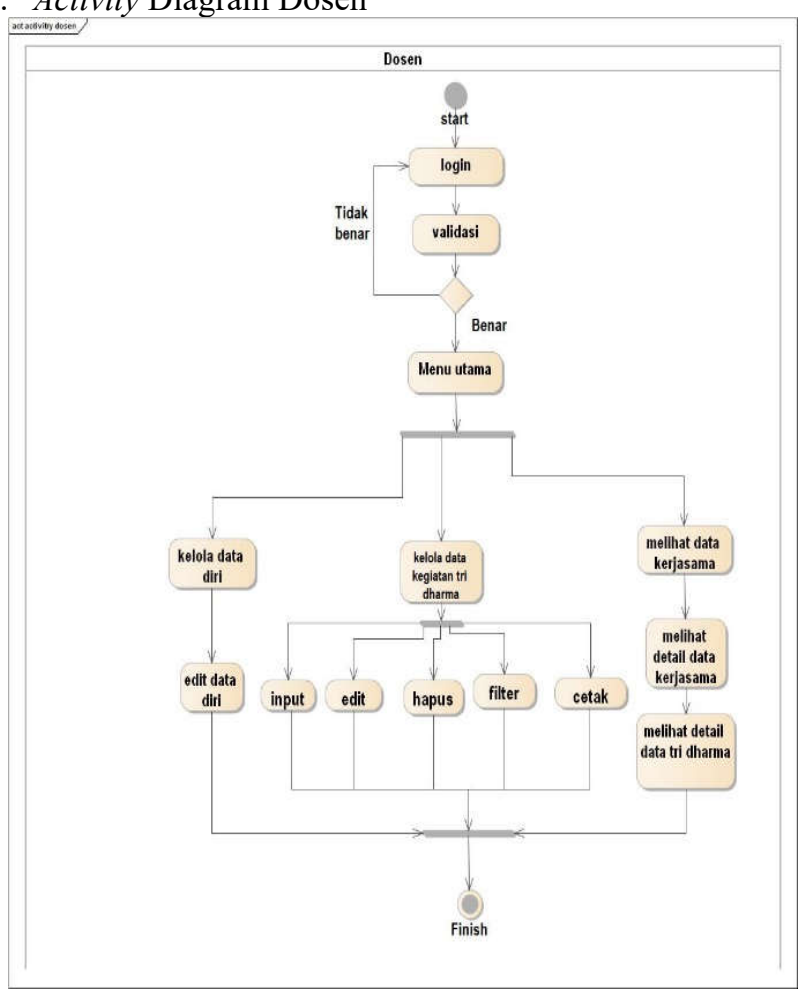

Gambar 5. Activity Diagram Dosen

5. Class Diagram

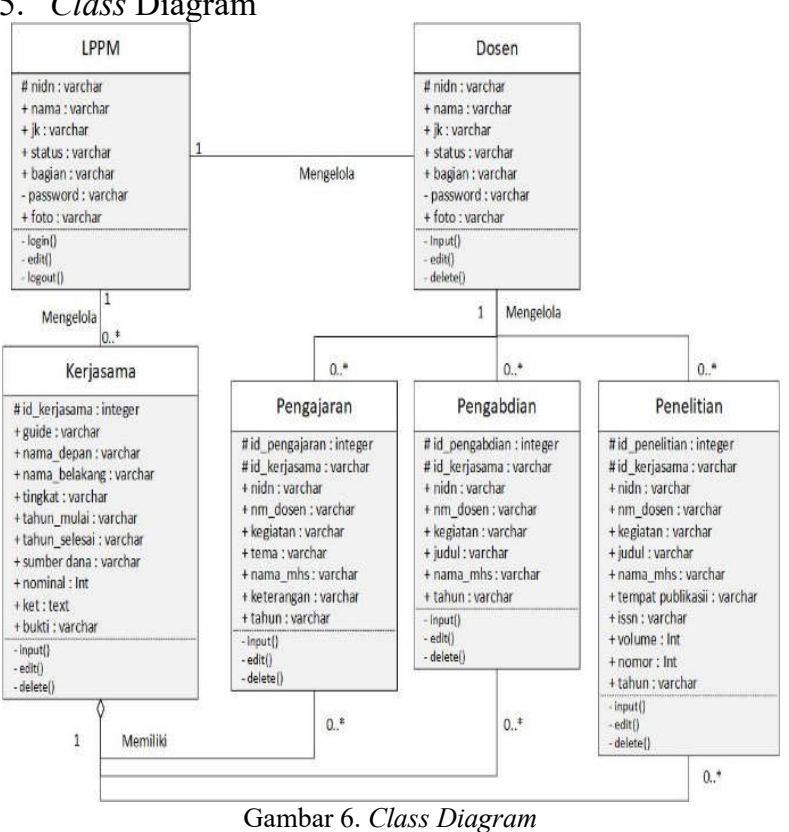

\section{B. Implementasi}

1. Form Login

Form ini berfungsi untuk akses masuk LPPM dan Dosen untuk mengakses sistem pengarsipan data kerjasama data tri dharma perguruan tinggi.

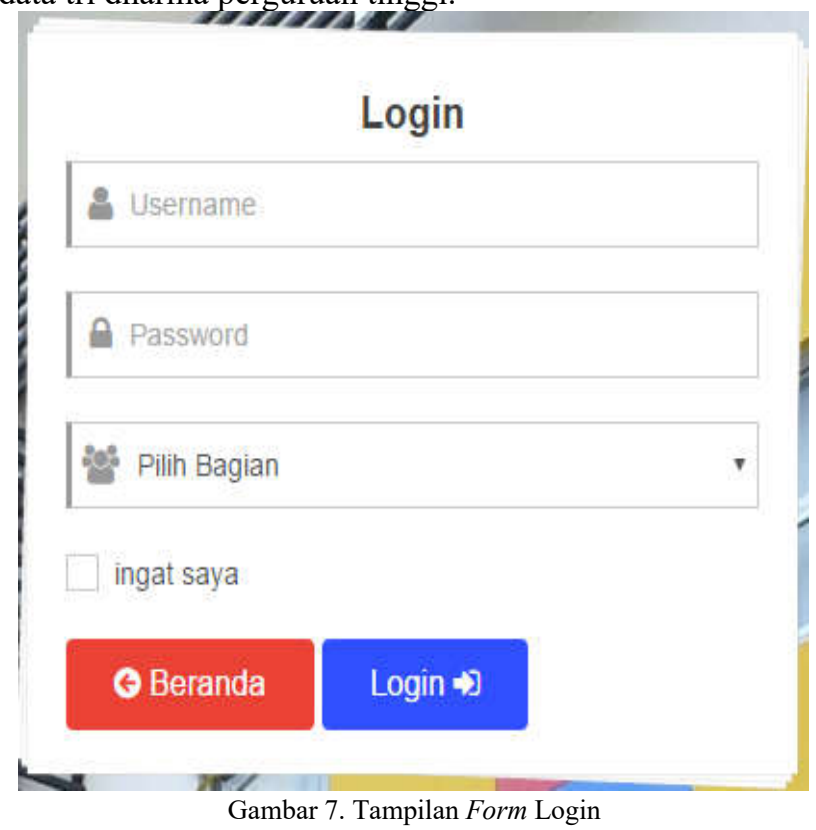

2. Tampilan Input Data Kerjasama

Form Input data kerjasama berfungsi untuk memasukan data kerjasama dan disimpan kedalam database. 


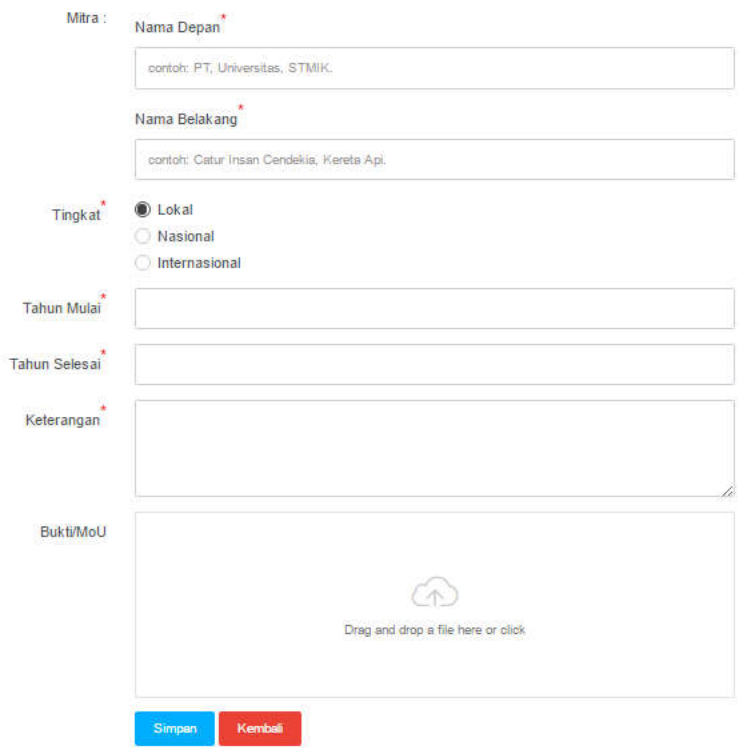

Gambar 8. Form Input Kerjasama

3. Tampilan Input Data Pengajaran

Form Input data kegiatan pengajaran berfungsi untuk memasukan data kegiatan pengajaran dosen dan disimpan kedalam database.

$\equiv \quad$ Input Pengajaran

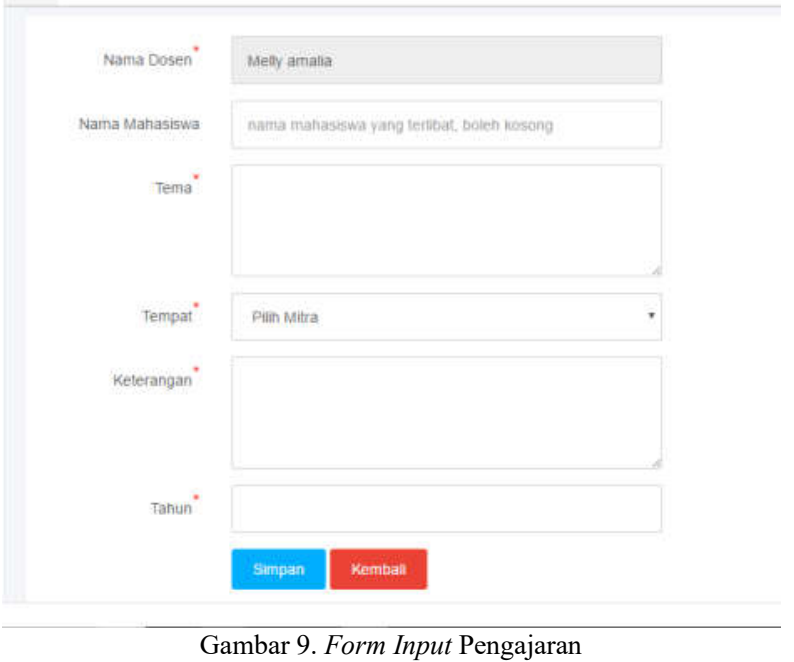

4. Tampilan Input Data Penelitian

Form Input data kegiatan penelitian berfungsi untuk memasukan data kegiatan penelitian dosen dan disimpan kedalam database.

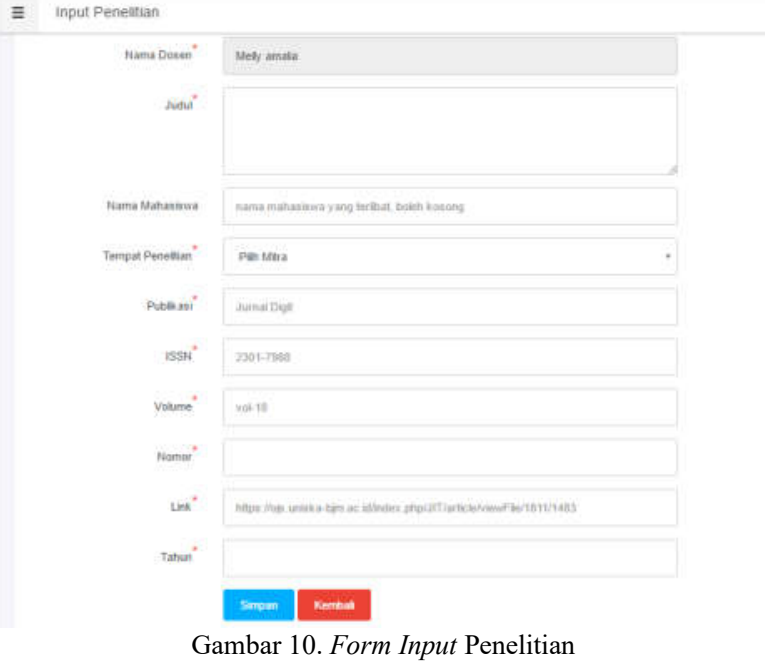

5. Tampilan Input Data Pengabdian

Form Input data kegiatan pengabdian berfungsi untuk memasukan data kegiatan pengabdian dosen dan disimpan kedalam database.

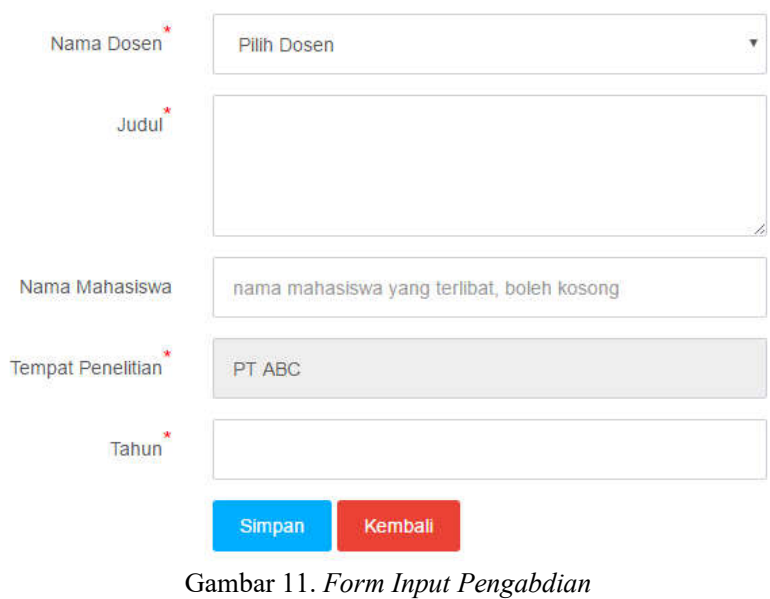

6. Tampilan Pembatas / Guide Arsip Kerjasama Dan Tabel Indeks Arsip Kerjasama

Setelah memasukan data kerjasama maka akan tampil output berupa tabel indeks data kerjasama, untuk melihat tabel indeks tersebut, pengguna harus membuka menu data kerjasama kemudian akan tampil folder arsip dari abjad A$\mathrm{Z}$, pengguna harus membuka salah satu folder tersebut untuk membuka tabel indeks kerjasama.

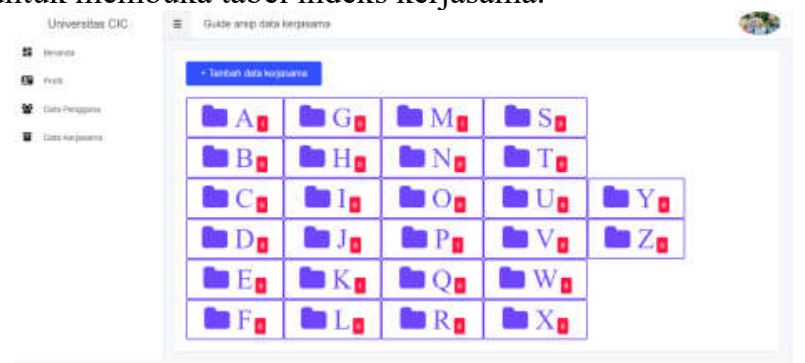

Gambar 12. Form Guide / folder 


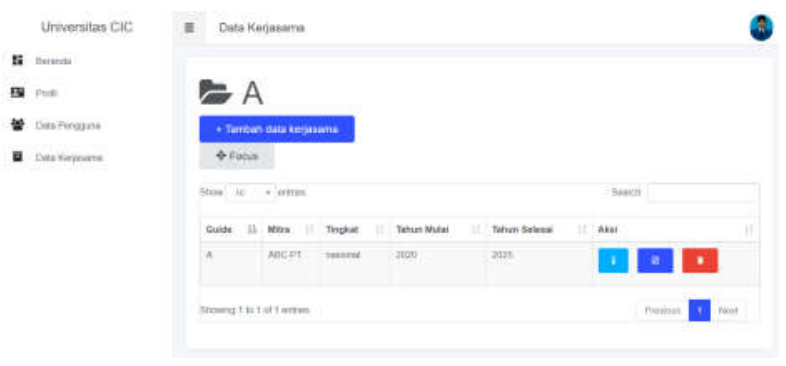

Gambar 13. Form Tabel Indeks

7. Tampilan Detail Data Kerjasama

Ketika membuka form detail data kerjasama maka akan tampil detail data kerjasama, pengajaran, penelitian dan pengabdian.

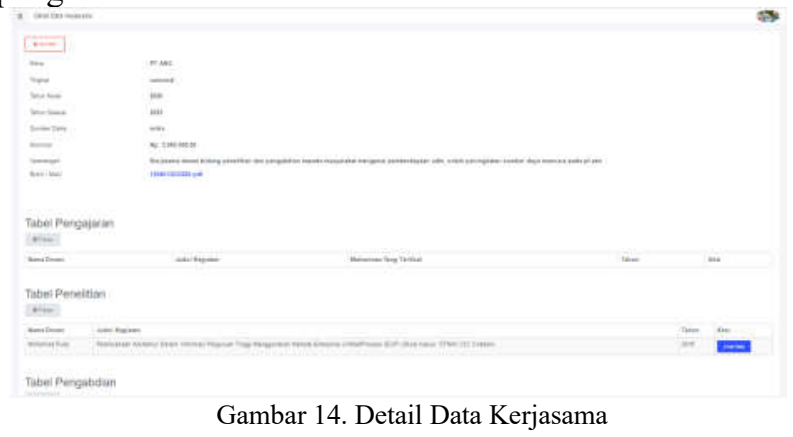

\section{Pengujian}

1. Pengujian Form Login

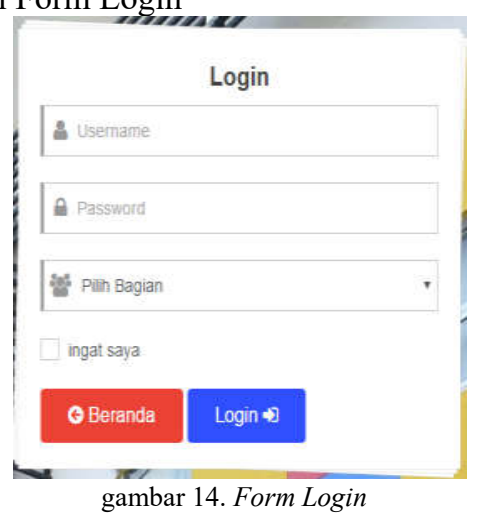

Tabel I

Hasil Pengujian Form Login

\begin{tabular}{|c|c|c|c|c|c|}
\hline No & $\begin{array}{c}\text { Jenis } \\
\text { Uji }\end{array}$ & Data Uji & $\begin{array}{l}\text { Hasil yang } \\
\text { Diharapkan }\end{array}$ & $\begin{array}{c}\text { Hasil } \\
\text { Keluaran }\end{array}$ & \begin{tabular}{|c|} 
Hasil \\
Uji \\
\end{tabular} \\
\hline 1 & $\begin{array}{l}\text { Tombol } \\
\text { Login }\end{array}$ & $\begin{array}{l}\text { Text box } \\
\text { username } \\
\text { kosong }\end{array}$ & $\begin{array}{l}\text { Muncul Please } \\
\text { fill out this } \\
\text { field }\end{array}$ & $\begin{array}{l}\text { Muncul } \\
\text { pesan }\end{array}$ & Valid \\
\hline 2 & $\begin{array}{l}\text { Tombol } \\
\text { Login }\end{array}$ & $\begin{array}{l}\text { Text box } \\
\text { password } \\
\text { kosong }\end{array}$ & \begin{tabular}{l}
\multicolumn{1}{c}{ Muncul } \\
Please fill out \\
this field
\end{tabular} & $\begin{array}{l}\text { Muncul } \\
\text { pesan }\end{array}$ & Valid \\
\hline 3 & $\begin{array}{l}\text { Tombol } \\
\text { Login }\end{array}$ & $\begin{array}{l}\text { Dropdown } \\
\text { bagian } \\
\text { kosong }\end{array}$ & $\begin{array}{l}\text { Muncul Please } \\
\text { select an item } \\
\text { in the list }\end{array}$ & $\begin{array}{l}\text { Muncul } \\
\text { pesan }\end{array}$ & val \\
\hline
\end{tabular}

\begin{tabular}{|c|l|l|l|l|l|}
\hline 4 & $\begin{array}{l}\text { Tombol } \\
\text { Login }\end{array}$ & $\begin{array}{l}\text { Semua Text } \\
\text { box kosong }\end{array}$ & $\begin{array}{l}\text { Muncul Please } \\
\text { fill out this } \\
\text { field }\end{array}$ & $\begin{array}{l}\text { Muncul } \\
\text { pesan }\end{array}$ & Valid \\
\hline 5 & $\begin{array}{l}\text { Tombol } \\
\text { Login }\end{array}$ & $\begin{array}{l}\text { Semua Text } \\
\text { box diisi } \\
\text { sesuai data }\end{array}$ & $\begin{array}{l}\text { Masuk ke } \\
\text { halaman } \\
\text { beranda }\end{array}$ & $\begin{array}{l}\text { Masuk ke } \\
\text { halaman } \\
\text { beranda }\end{array}$ & Valid \\
\hline
\end{tabular}

Keterangan :

Dalam form login terdapat tombol login dan tombol beranda, apabila kita klik tombol login atau beranda dalam keadaan kondisi yang sesuai dengan ketentuan pada tabel, maka dinyatakan valid.

\section{Pengujian Form Beranda}
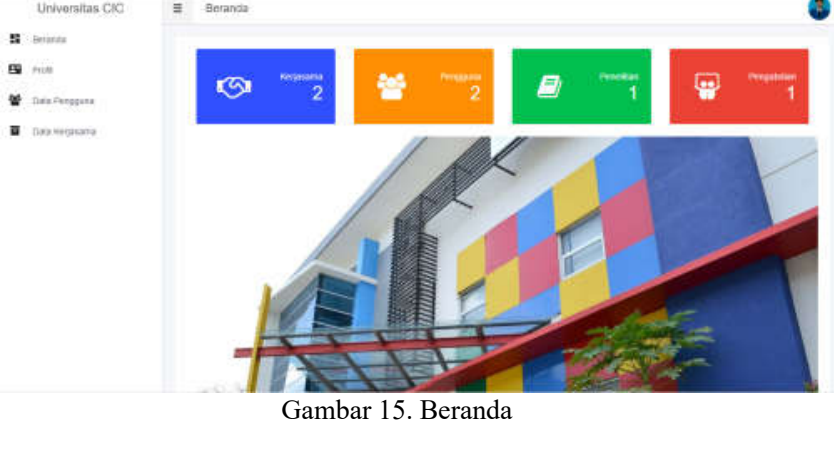

TABEL II

Pengujian Form Beranda

\begin{tabular}{|c|l|l|l|l|l|}
\hline No & Jenis Uji & Data Uji & $\begin{array}{c}\text { Hasil yang } \\
\text { Diharapkan }\end{array}$ & $\begin{array}{c}\text { Hasil } \\
\text { Keluaran }\end{array}$ & $\begin{array}{c}\text { Hasil } \\
\text { Uji }\end{array}$ \\
\hline 1 & Beranda & $\begin{array}{l}\text { Klik menu } \\
\text { beranda }\end{array}$ & $\begin{array}{l}\text { Tampil } \\
\text { halaman } \\
\text { beranda }\end{array}$ & $\begin{array}{l}\text { Tampil } \\
\text { halaman } \\
\text { beranda }\end{array}$ & Valid \\
\hline 2 & Profil & $\begin{array}{l}\text { Klik menu } \\
\text { profil }\end{array}$ & $\begin{array}{l}\text { Tampil profil } \\
\text { data diri }\end{array}$ & $\begin{array}{l}\text { Tampil profil } \\
\text { data diri }\end{array}$ & Valid \\
\hline 3 & $\begin{array}{l}\text { Data } \\
\text { Pengguna }\end{array}$ & $\begin{array}{l}\text { Klik menu } \\
\text { data } \\
\text { pengguna }\end{array}$ & $\begin{array}{l}\text { Tampil tabel } \\
\text { data pengguna }\end{array}$ & $\begin{array}{l}\text { Tampil tabel } \\
\text { data pengguna }\end{array}$ & Valid \\
\hline 4 & $\begin{array}{l}\text { Data } \\
\text { Kerjasama }\end{array}$ & $\begin{array}{l}\text { Klik menu } \\
\text { data } \\
\text { kerjasama }\end{array}$ & $\begin{array}{l}\text { Tampil guide } \\
\text { arsip data } \\
\text { kerjasama }\end{array}$ & $\begin{array}{l}\text { Tampil guide } \\
\text { arsip data } \\
\text { kerjasama }\end{array}$ & Valid \\
\hline
\end{tabular}

Keterangan :

Dalam menu form beranda terdapat tampilan informasi singkat mengenai data kerjasama dan tri dharma perguruan tinggi, kemudian terdapat tombol menu pada left menu, pada menu-menu tersebut dapat membuka form-form menu yang ada pada aplikasi, apabila menu-menu tersebut kita klik, maka apabila sudah ssuai dengan ketentuan yang ada pada tabel pengujian, maka dinyatakan valid. 
3. Pengujian Form Input Data Kerjasama

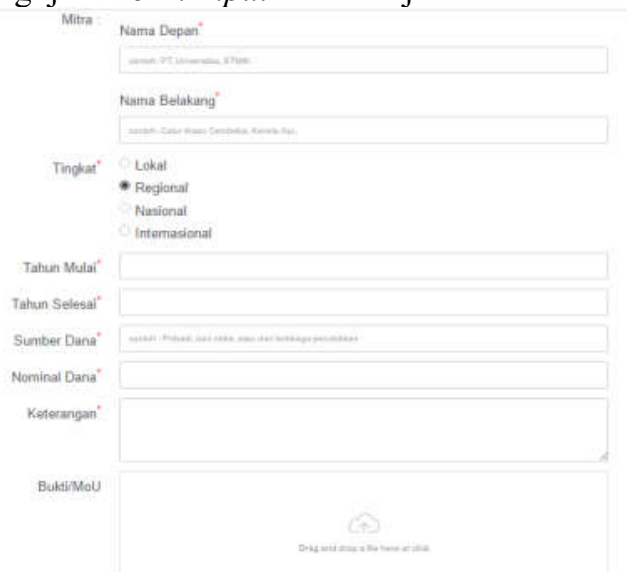

\begin{tabular}{|c|c|c|c|c|c|}
\hline \multicolumn{6}{|c|}{$\begin{array}{c}\text { Gambar 16. Form Input Kerjasama } \\
\text { TABEL III } \\
\text { Pengujian Form Input Kerjasama }\end{array}$} \\
\hline No & Jenis Uji & Data Uji & $\begin{array}{l}\text { Hasil yang } \\
\text { Diharapkan }\end{array}$ & $\begin{array}{c}\text { Hasil } \\
\text { Keluaran }\end{array}$ & $\begin{array}{c}\text { Hasil } \\
\text { Uji }\end{array}$ \\
\hline 1 & $\begin{array}{l}\text { Tombol } \\
\text { Simpan }\end{array}$ & $\begin{array}{l}\text { Text box } \\
\text { kosong }\end{array}$ & $\begin{array}{l}\text { Muncul pesan } \\
\text { Please fill out } \\
\text { this field }\end{array}$ & Muncul pesan & Valid \\
\hline 2 & $\begin{array}{l}\text { Tombol } \\
\text { Simpan }\end{array}$ & $\begin{array}{l}\text { Text box } \\
\text { Sebagian } \\
\text { kosong }\end{array}$ & $\begin{array}{l}\text { Muncul pesan } \\
\text { Please fill out } \\
\text { this field }\end{array}$ & Muncul pesan & Valid \\
\hline 3 & $\begin{array}{l}\text { Tombol } \\
\text { Simpan }\end{array}$ & $\begin{array}{l}\text { Text box } \\
\text { Semua } \\
\text { diisi }\end{array}$ & $\begin{array}{l}\text { Data } \\
\text { tersimpan }\end{array}$ & $\begin{array}{l}\text { Tampil data } \\
\text { pada tabel } \\
\text { indeks data } \\
\text { kerjasama }\end{array}$ & Valid \\
\hline 4 & $\begin{array}{l}\text { Tombol } \\
\text { Simpan }\end{array}$ & $\begin{array}{l}\text { Text box } \\
\text { kosong }\end{array}$ & $\begin{array}{l}\text { Muncul pesan } \\
\text { Please fill out } \\
\text { this field }\end{array}$ & Muncul pesan & Valid \\
\hline
\end{tabular}

Keterangan :

Pada from input data kerjasama terdapat beberapa text field dan tombol, apabila pada pengujian sesuai dengan ketentuan pada tabel diatas, maka dinyatakan valid.

\section{Pengujian Form Input Data Pengajaran}

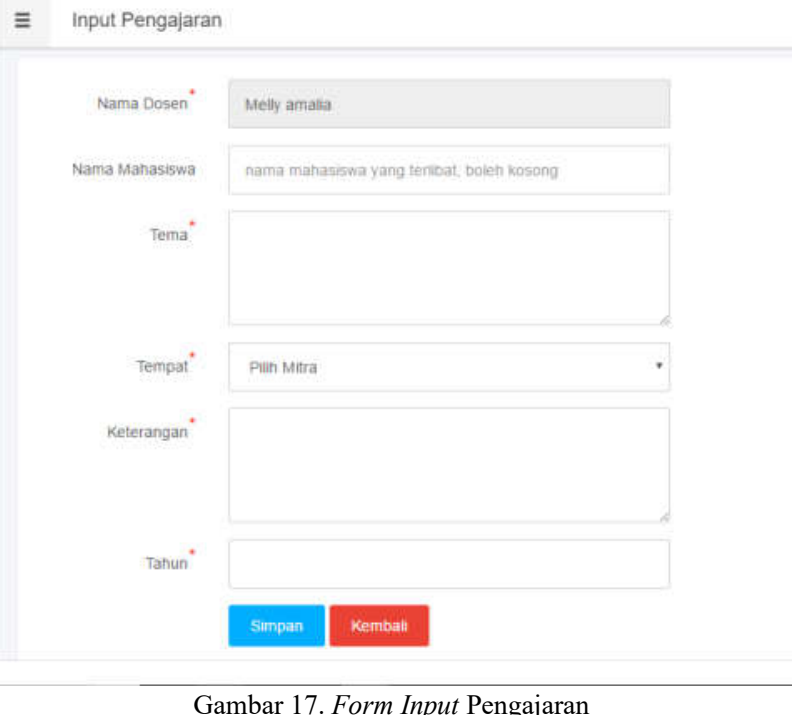

TABEL IV

Pengujian Form Input Pengajaran

\begin{tabular}{|c|c|c|c|c|c|}
\hline No & Jenis $\mathrm{Uji}$ & Data Uji & $\begin{array}{c}\text { Hasil yang } \\
\text { Diharapkan }\end{array}$ & $\begin{array}{c}\text { Hasil } \\
\text { Keluaran } \\
\end{array}$ & $\begin{array}{c}\text { Hasil } \\
\text { Uji } \\
\end{array}$ \\
\hline 1 & $\begin{array}{l}\text { Tombol } \\
\text { Simpan }\end{array}$ & $\begin{array}{l}\text { Text box } \\
\text { sebagian } \\
\text { kosong }\end{array}$ & $\begin{array}{l}\text { Muncul } \\
\text { Please fill out } \\
\text { this field }\end{array}$ & Muncul pesan & Valid \\
\hline 2 & $\begin{array}{l}\text { Tombol } \\
\text { Simpan }\end{array}$ & $\begin{array}{l}\text { Text box } \\
\text { semua } \\
\text { kosong }\end{array}$ & $\begin{array}{l}\text { Muncul } \\
\text { Please fill out } \\
\text { this field }\end{array}$ & Muncul pesan & Valid \\
\hline 3 & $\begin{array}{l}\text { Tombol } \\
\text { Simpan }\end{array}$ & $\begin{array}{l}\text { Text box } \\
\text { semua } \\
\text { diisi }\end{array}$ & $\begin{array}{l}\text { Data } \\
\text { tersimpan }\end{array}$ & $\begin{array}{l}\text { Data } \\
\text { tersimpan dan } \\
\text { tampil } \\
\text { halaman data } \\
\text { kegiatan }\end{array}$ & valid \\
\hline 4 & $\begin{array}{l}\text { Tombol } \\
\text { kembali }\end{array}$ & $\begin{array}{l}\text { Klik } \\
\text { tombol } \\
\text { kembali }\end{array}$ & $\begin{array}{l}\text { Tampil } \\
\text { halaman data } \\
\text { kegiatan }\end{array}$ & $\begin{array}{l}\text { Tampil } \\
\text { halaman data } \\
\text { kegiatan }\end{array}$ & Valid \\
\hline
\end{tabular}

Keterangan :

Pada from input data pengajaran terdapat beberapa text field dan tombol, apabila pada pengujian sesuai dengan ketentuan pada tabel diatas, maka dinyatakan valid.

5. Pengujian Form Input Data Penelitian 


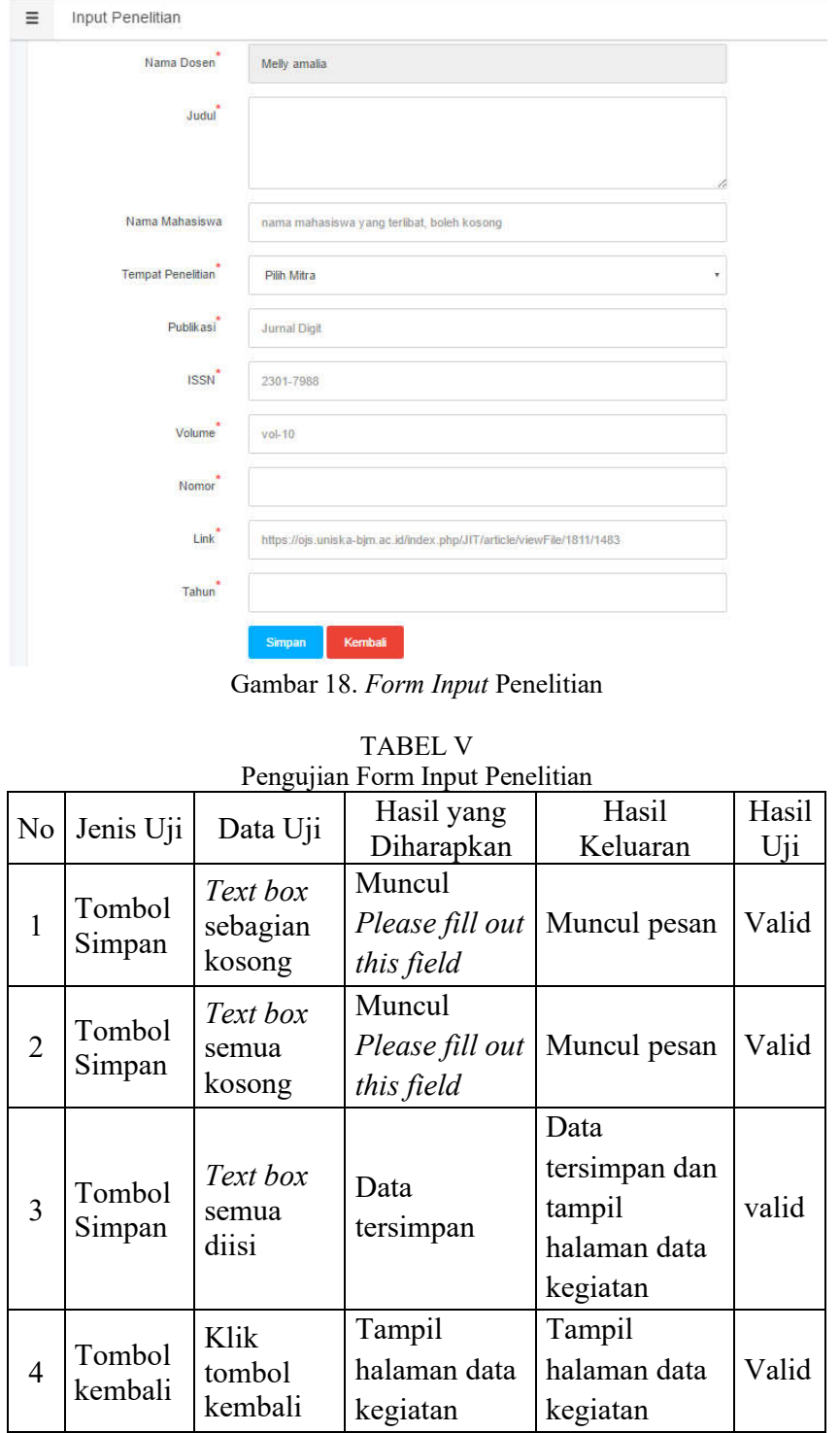

Keterangan :

Pada from input data penelitian terdapat beberapa text field dan tombol, apabila pada pengujian sesuai dengan ketentuan pada tabel diatas, maka dinyatakan valid.

\section{Pengujian Form Input Data Pengabdian}

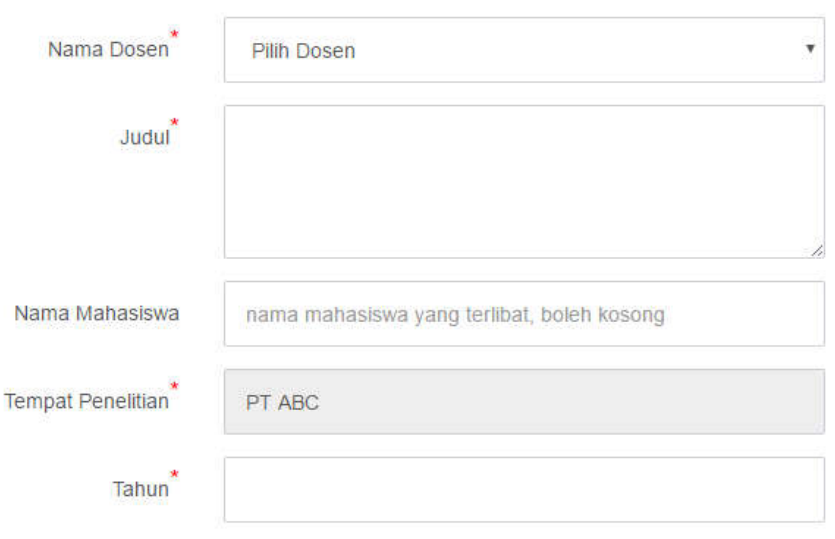

\section{Simpan Kembali}

Gambar 19. Form Input Pengabdian

Tabel VI

Pengujian From Input Data Pengabdian

\begin{tabular}{|c|c|c|c|c|c|}
\hline No & Jenis Uji & Data Uji & $\begin{array}{l}\text { Hasil yang } \\
\text { Diharapkan }\end{array}$ & Hasil Keluaran & $\begin{array}{c}\text { Hasil } \\
\text { Uji } \\
\end{array}$ \\
\hline 1 & $\begin{array}{l}\text { Tombol } \\
\text { Simpan }\end{array}$ & $\begin{array}{l}\text { Text box } \\
\text { sebagian } \\
\text { kosong }\end{array}$ & $\begin{array}{l}\text { Muncul } \\
\text { Please fill out } \\
\text { this field }\end{array}$ & Muncul pesan & Valid \\
\hline 2 & $\begin{array}{l}\text { Tombol } \\
\text { Simpan }\end{array}$ & $\begin{array}{l}\text { Text box } \\
\text { semua } \\
\text { kosong }\end{array}$ & $\begin{array}{l}\text { Muncul } \\
\text { Please fill out } \\
\text { this field }\end{array}$ & Muncul pesan & Valid \\
\hline 3 & $\begin{array}{l}\text { Tombol } \\
\text { Simpan }\end{array}$ & $\begin{array}{l}\text { Text box } \\
\text { semua } \\
\text { diisi }\end{array}$ & $\begin{array}{l}\text { Data } \\
\text { tersimpan }\end{array}$ & $\begin{array}{l}\text { Data tersimpan } \\
\text { dan tampil } \\
\text { halaman detail } \\
\text { data kerjasama }\end{array}$ & valid \\
\hline 4 & $\begin{array}{l}\text { Tombol } \\
\text { kembali }\end{array}$ & $\begin{array}{l}\text { Klik } \\
\text { tombol } \\
\text { kembali }\end{array}$ & $\begin{array}{l}\text { Tampil } \\
\text { halaman } \\
\text { tabel } \\
\text { pengguna }\end{array}$ & $\begin{array}{l}\text { Tampil } \\
\text { halaman detail } \\
\text { data kerjasama }\end{array}$ & Valid \\
\hline
\end{tabular}

Keterangan :

Pada from input data pengabdian terdapat beberapa text field dan tombol, apabila pada pengujian sesuai dengan ketentuan pada tabel diatas, maka dinyatakan valid.

7. Pengujian Form Arsip Guide / Folder Data Kerjasama

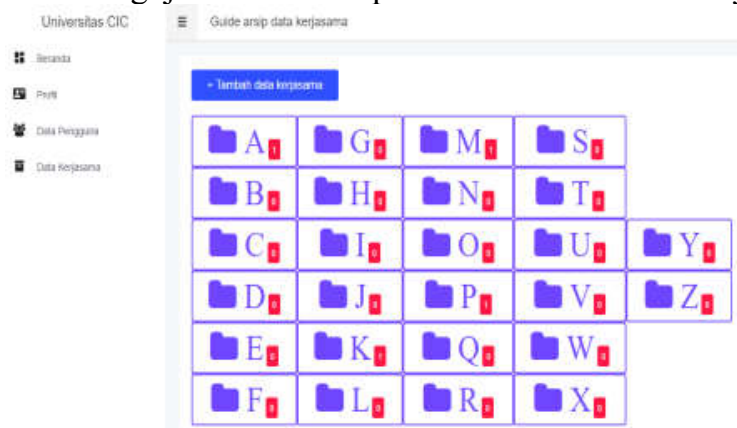

Gambar 20. Form Arsip Guide / Folder Data Kerjasama 
TABEL VII

Pengujian Form Arsip Guide / Folder Data Kerjasama

\begin{tabular}{|c|c|c|c|c|c|}
\hline No & Jenis $\mathrm{Uji}$ & Data Uji & $\begin{array}{l}\text { Hasil yang } \\
\text { Diharapkan }\end{array}$ & $\begin{array}{c}\text { Hasil } \\
\text { Keluaran }\end{array}$ & $\begin{array}{c}\text { Hasil } \\
\text { Uji }\end{array}$ \\
\hline 1 & $\begin{array}{l}\text { Tombol } \\
\text { tambah } \\
\text { data } \\
\text { kerjasama }\end{array}$ & $\begin{array}{l}\text { Klik } \\
\text { tombol } \\
\text { tambah } \\
\text { data } \\
\text { kerjasama }\end{array}$ & $\begin{array}{l}\text { Tampil } \\
\text { halaman } \\
\text { input data } \\
\text { kerjasama }\end{array}$ & $\begin{array}{l}\text { Tampil } \\
\text { halaman } \\
\text { input data } \\
\text { kerjasama }\end{array}$ & Valid \\
\hline 2 & $\begin{array}{l}\text { Folder / } \\
\text { Guide }\end{array}$ & $\begin{array}{l}\text { Klik icon } \\
\text { Folder }\end{array}$ & $\begin{array}{l}\text { Tampil } \\
\text { halaman } \\
\text { indeks tabel } \\
\text { data } \\
\text { kerjasama }\end{array}$ & $\begin{array}{l}\text { Tampil } \\
\text { halaman } \\
\text { indeks tabel } \\
\text { data } \\
\text { kerjasama }\end{array}$ & Valid \\
\hline
\end{tabular}

Keterangan :

Pada form arsip data kerjasama terdapat folder dan tombol tambah data kerjasama, apabila pengujian sudah sesuai dengan tabel di atas, maka dinyatakan valid.

\section{Pengujian Tabel Indeks Data Kerjasama}

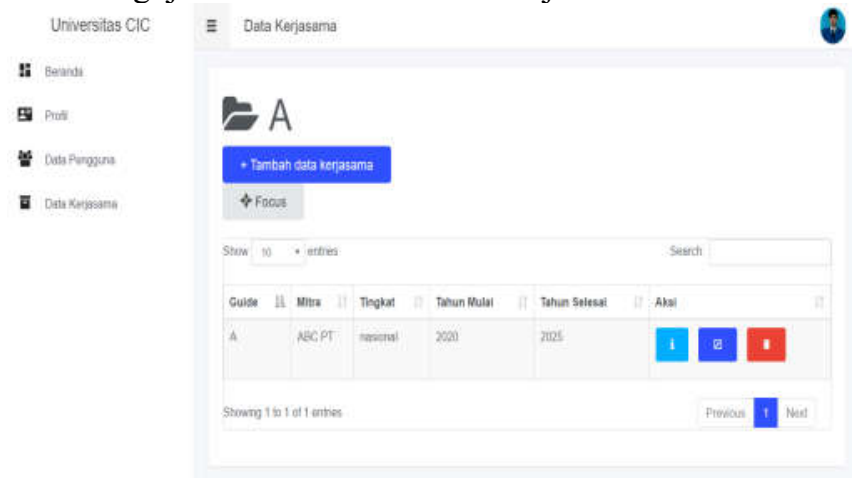

Gambar 21. Tabel Indeks Data Kerjasama

TABEL VIII

Pengujian Form Tabel Indeks

\begin{tabular}{|c|l|l|l|l|l|}
\hline No & Jenis Uji & \multicolumn{1}{|c|}{ Data Uji } & $\begin{array}{l}\text { Hasil yang } \\
\text { Diharapkan }\end{array}$ & $\begin{array}{l}\text { Hasil } \\
\text { Keluaran }\end{array}$ & $\begin{array}{c}\text { Hasil } \\
\text { Uji }\end{array}$ \\
\hline $\begin{array}{l}\text { tambah } \\
\text { data } \\
\text { kerjasama }\end{array}$ & $\begin{array}{l}\text { Klik } \\
\text { tombol } \\
\text { tambah } \\
\text { data } \\
\text { kerjasama }\end{array}$ & $\begin{array}{l}\text { Tampil } \\
\text { halaman } \\
\text { input } \text { data } \\
\text { kerjasama }\end{array}$ & $\begin{array}{l}\text { Tampil } \\
\text { halaman } \\
\text { input data } \\
\text { kerjasama }\end{array}$ & Valid \\
\hline $\begin{array}{l}\text { Tombol } \text { detail } \\
\text { data } \\
\text { kerjasama }\end{array}$ & $\begin{array}{l}\text { Klik } \\
\text { tombol } \\
\text { icon } \text { detail } \\
\text { data } \\
\text { kerjasama }\end{array}$ & $\begin{array}{l}\text { Tampil } \\
\text { halaman } \\
\text { detail data } \\
\text { kerjasama }\end{array}$ & $\begin{array}{l}\text { Tampil } \\
\text { halaman } \\
\text { detail data } \\
\text { kerjasama }\end{array}$ & Valid \\
\hline $\begin{array}{l}\text { Tombol } \text { edit } \\
\text { data } \\
\text { kerjasama }\end{array}$ & $\begin{array}{l}\text { Klik } \\
\text { tombol } \\
\text { icon } \text { edit } \\
\text { data } \\
\text { kerjasama }\end{array}$ & $\begin{array}{l}\text { Tampil } \\
\text { halaman } \text { edit } \\
\text { data } \\
\text { kerjasama }\end{array}$ & $\begin{array}{l}\text { Tampil } \\
\text { halaman } \\
\text { edit } \text { data } \\
\text { kerjasama }\end{array}$ & Valid \\
\hline 4 & $\begin{array}{l}\text { Tombol } \\
\text { icon hapus } \\
\text { data } \\
\text { kerjasama }\end{array}$ & $\begin{array}{l}\text { Klik } \\
\text { tombol } \\
\text { icon hapus } \\
\text { data } \\
\text { kerjasama }\end{array}$ & $\begin{array}{l}\text { Muncul } \\
\text { pesan hapus } \\
\text { data } ?\end{array}$ & $\begin{array}{l}\text { Muncul } \\
\text { pesan }\end{array}$ & Valid \\
\hline
\end{tabular}

Keterangan :
Pada form tabel indeks data kerjasama, terdapat tabel dan tombol, apabila pengujian sudah sesuai pada tabel di atas, maka dinyatakan valid.

\section{KESIMPULAN}

Dari hasil penelitian yang telah dilakukan, dapat disimpulkan penelitian ini berhasil membangun Sistem Informasi Pengelolaan Arsip Data Kerjasama Tri Dharma Perguruan Tinggi Berbasis WEB Menggunakan Metode Alphabetical Filing System . Serta dapat menjawab rumusan masalah yang telah di definisikan sebelumnya.

- Sistem yang telah dibuat diharapkan dapat mempermudah Lembaga Penelitian Dan Pengabdian Masyarakat dalam melakukan pengarsipan data.

- Kearsipan elektronik diharapkan menjadi media pengarsipan data yang aman dan efisien dalam penyimpanan data.

- Sistem yang telah dibuat diharapkan dapat memenuhi efisisensi dalam pengarsipan data kerjasama tri dharma perguruan tinggi.

\section{UCAPAN TERIMA KASIH}

Terimakasih kepada team riviewer jurnal PETIK yang telah meluangkan waktunya untuk melihat karya ilmiah yang kami buat, semoga karya ilmiah ini dapat bermanfaat bagi kita semua.

\section{DAFTAR PUSTAKA}

[1] P. Sokibi, "Pembuatan Perangkat Lunak Sistem Informasi Penjualan Tunai Berbasis WEB Di PT. Propan Raya Cirebon," ITEJ (Information Technol. Eng. Journals), vol. 1, no. 2, 2017.

[2] Imasita, A. Gunawan, and Hirman, "Pengembangan Model Sistem Pengelolaan Dokumen Tri Dharma pada Politeknik Negeri Ujung Pandang Berbasis Web," J. Inf. Sains dan Teknol., vol. 4, no. 1, 2019.

[3] W. Welda and B. A. Minartiningtyas, "Sistem Informasi Pengelolaan Kerjasama Bidang Humas pada STMIK STIKOM Indonesia," $J$. Sisfokom (Sistem Inf. dan Komputer), vol. 6, no. 2, p. 86, 2017, doi: 10.32736/sisfokom.v6i2.252.

[4] D. Ratnasari and H. A.Tawakal, "Analisis Dan Perancangan Aplikasi Sistem Informasi Penelitian Dan Pengabdian Masyarakat Lppm Stt Terpadu Nurul Fikri," J. Inform. Terpadu, vol. 3, no. 1, pp. 227-243, 2017.

[5] P. Roger, Rekayasa Perangkat Lunak, Praktisi. (Buku I), 2017.

[6] P. Irawan, D. Prasetia, and P. Sokibi, "Rancang Bangun Sistem Pengarsipan Surat Kedinasan Berbasis Web Menggunakan Framework Codeigniter," J. Manaj. Inform. Sist. Inf., vol. 3, no. 2, pp. 157-165, 2020.

[7] G. B. Davis, Sistem Informasi Manajemen. PT. Pustaka Binaman, 1995.

[8] M. Ray Jr, Sistem Informasi Manajemen. Jakarta: PT. Prenhalindo, 1995.

[9] Kertahadi, Sistem Informasi Manajemen / Kertahadi dan Endang Siti Astuti Azis. Malang: IKIP MALANG, 1995.

[10] Imasita, A. Gunawan, and Hirman, "Model Penyimpanan Dokumen Tri Dharma Perguruan Tinggi Terintegrasi Dengan Dokumen Dosen Berbasis Web," Pros. Semin. Nas. Akutansi, Manajemen, dan Keuang. ke III, 2018 Jur. Akunt. Politek. Negeri Malang, pp. 71-80, 2018.

[11] S. Pamudji, Kerjasama antar daerah dalam rangka pembinaan 
wilayah: suatu tinjauan dari segi administrasi negara / S. Pamudji. Jakarta: Bina Aksara, 1985.

[12] Syafriwaldi, "Kerjasama Penyuluh Agama Islam Fungsional Dengan Aparat Kelurahan Dalam Mengatasi Penyakit Masyakarakat Di Kelurahan Purus Kecamatan Padang Barat Kota Padang,” J. Al-Fuad, vol. 2, no. 2, pp. 251-265, 2018, doi: http://dx.doi.org/10.31958/jsk.v2i2.1441.

[13] N. Machfud, "Persepsi mahasiswa dalam mengimplementasikan tri dharma perguruan tinggi di institut agama islam negeri (iain) salatiga tahun 2015/2016," J. Al-Fuad, vol. 1, no. 1, pp. 44-53, 2017.

[14] R. Ria, L. Listiyoko, M. Saragih, and A. Presilia, "Sistem Pengelolaan Dokumen Surat Menggunakan Metode Alphabetical Filing Dan Chronology System," J. Komput. dan Inform., vol. 15, no. 1, pp. 192200, 2020.

[15] R. Pressman, Software Engineering A Practitioner's Approach, Edisi ke 6. New York: McGraw-Hill, 2005.

[16] C. Trintianto, "Penggunaan Metode Waterfall Untuk Pengembangan Sistem Monitoring Dan Evaluasi Pembangunan Pedesaan," J. Teknol. Inf. ESIT, vol. 12, no. 01, pp. 8-22, 2018, doi: 10.5749/j.cttttv6b.5. 